\title{
Global Crisis, Innovation and Change Management: Towards a New Systemic Perception of the Current Globalization Restructuring
}

\author{
Charis Michael Vlados ${ }^{1}$, Nikolaos Deniozos ${ }^{1}$, Demosthenes Chatzinikolaou ${ }^{2}$ \\ ${ }^{1}$ Department of Economics, Democritus University of Thrace, Greece \\ ${ }^{2}$ School of Law, Post-Graduate Courses in South-Eastern Europe Studies, Specialization in Economics, \\ Democritus University of Thrace, Greece \\ Correspondence: Demosthenes Chatzinikolaou, School of Law, Post-Graduate Courses in South-Eastern Europe \\ Studies, Specialization in Economics, Democritus University of Thrace, Greece.
}

\author{
Received: June 19, 2018 \\ Accepted: July 4, 2018 \\ Online Published: July 6, 2018 \\ doi:10.5539/ibr.v11n8p9 \\ URL: https://doi.org/10.5539/ibr.v11n8p9
}

\begin{abstract}
The "crisis of capitalism" is not, of course, an unprecedented discourse in the evolution of economics and the investigation of economic realities. In Neo-Schumpeterian economics crises constitute necessary evolutionary steps, intrinsically linked with breaking 'moments' and change. However, what makes the current crisis clearly different, and to a large extent subversive, is its ever increasing complexity and evolutionary-dialectic substance. The mixing of cooperation and competition, on an organizational and macro-economic level, reproduces on a global scale the need for a reconsideration of basic economic mechanisms. It tends to undermine and rapidly destroy the mechanistic relations and structures of all kinds and dimensions that have managed to provide profitability and effectiveness over the recent years. In this context, the search for strategic innovation, constant organizational renewal and the diffusion of production oriented at high technological expertise, seem to progressively become the critical synthetic components for building a new development model at all levels and for all agents of action.

This paper focuses on the introduction of a three tier question which could be put forward as follows. First we ask what is the current global restructuring crisis and what would be a new growth model that would lead us to the exit of it on a global scale. Second we address the issue of what kind of innovation mechanisms does such a new model of interspatial restructuring and development require. Finally we analyse why is this new innovative direction - both in global terms and in individual socioeconomic systems - a prerequisite for building new types of effective change management mechanisms.

The starting point of our approach is the position that any fragmented approach in the individual aspects of the triangle of global crisis, innovation, and change management, is now analytically misguided and practically powerless. Only an effort to systemically understand the phenomenon, in its constant and dialectic structure, is now an adequate condition for outlining the future developmental path of globalization at all levels of action.
\end{abstract}

Keywords: change management, global crisis, globalization, innovation, realistic innovative liberalism, Stra.Tech.Man analysis

\section{Introduction: The Dialectical Connection between Global Crisis, Innovation, and Change Management}

The central task of this research is to focus on studying the closely related evolutionary interconnection of three fundamental dimensions/pillars of modern reality, namely the global economic crisis, innovation and change management, as these unfold at every level of action (Amable, 2000; Amable, 2002; Aglietta, 2008; Aoki, 2001; Artus, 2001; Boyer, 1986; Boyer, 2002; Coriat, Petit, \& Schmeder 2006; Esping-Andersen, 1990; Esping-Andersen, 1999; Gadrey \& Jany-Catrice, 2012; Stiglitz 2003a). This paper delves into the structural core of every organization, strategy, technology, and management (Stra.Tech.Man) which, in a deeper sense, shapes

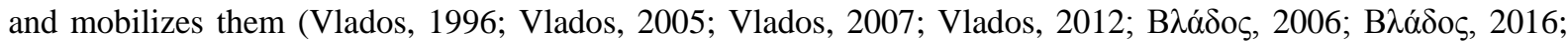
$\mathrm{B} \lambda \alpha \dot{\delta} \delta \mathrm{o}$, , 2017). In particular, we lay down this analysis on the interconnection level between global crisis, innovation and change management, which are required to overcome the first, in a process of global restructuring, towards a "new globalization" (Aglietta \& Rebérioux, 2004; Aglietta, 1998; Artus \& Virard, 2015; 
Boltansky \& Chiapello, 1999; Braudel, 2014; Brender \& Pisani, 2009; Chavagneux, 2011; Curien, 2000; Dobbs, 2015; Reich, 1993; Rifkin, 2002). In particular, we argue here that these three critical dimensions in the years of late modernity have been erroneously seen as unrelated, independent and self-explanatory, thus favoring a conceptual autonomy. In this paper we are facing the three most critical dimensions of modern reality, which - quite incorrectly, according to the alternative view we propose-are usually considered in modern literature as being unrelated, independent and self-explanatory-in their conceptual autonomy. An effective consideration, on the contrary, we think, is precisely one that opposes this fragmentary and analytically disruptive logic (Aglietta \& Orléan, 1982; Aglietta \& Orléan, 2002; Aglietta \& Brender, 1984; Benassy, Boyer, Gelpi, \& Lipietz, 1977; Billaudot, 1996; Billaudot, 2001; Boyer, 2004; Boyer \& Freyssenet, 2000; Chavance, 2012; Coriat, 1979; Coriat, 1994; Delorme \& André, 1983; Dulong, 2012; Lahire, 2005; Lipietz, 1979; Lipietz, 1983; Lordon, 2002; Orléan, 1999; Petit, 2005). (Figure 1).

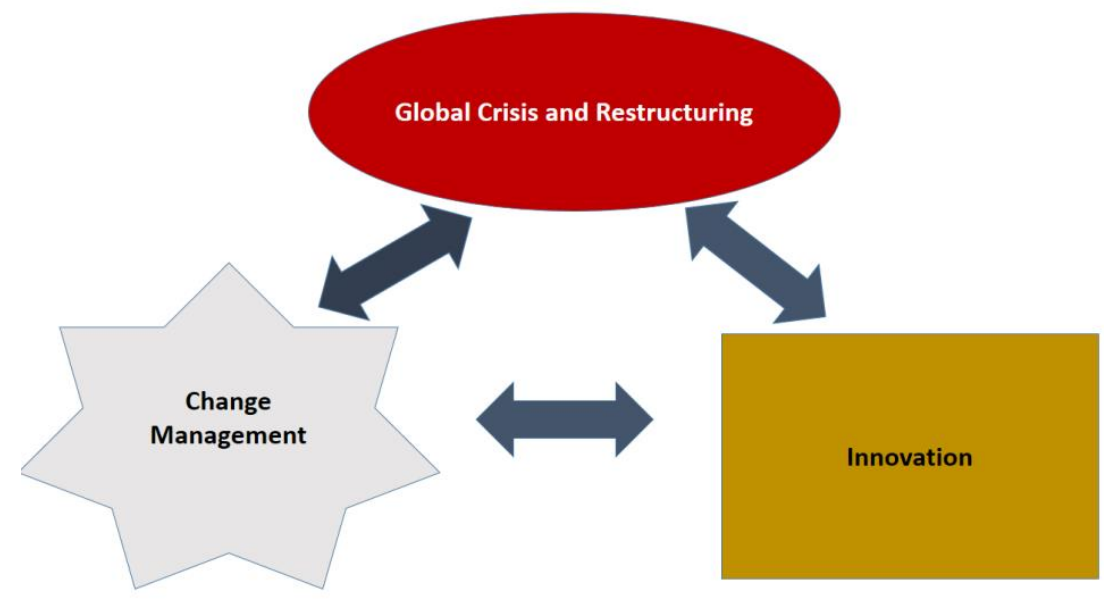

Figure 1. Global crisis and restructuring, innovation and change management

We consider that it is analytically misplaced and fruitless to try to approach any of these dimensions in the absence of the other two; you could never completely understand each of these spheres by looking at them separately one from another. As Tsoukas (Tsoukas, 2017) and other scholars recently argued, it is by bringing forward a complexification of concepts and by investigating social relations that may produce theoretical models that would link with real life and societal challenges. Consequently, the only way to conceive them all, in their analytical depth, is to explore them in their narrow evolutionary systemic interplay. In the next sections we will explore the various parts of this relationship.

\section{Elements of Literature Review on the Global Crisis}

What we have been experiencing since the end of the first decade of the $21^{\text {st }}$ century is historically unique and profoundly subversive to the "regime of things" we have been accustomed to over the recent decades. Of all the places that have the power to shape the dominant political perception and act in the global economy, today, the findings seem to be almost unanimous: Nothing in the world appears to balance, now, like it used to in the past (National Intelligence Council, 2008).

It becomes obvious that we live in a complex context of crisis, of increasing liquidity and uncertainty. A variety of complex dynamic dimensions (economic, social, developmental, political, institutional, demographic, cultural, religious, energetic, climatic, geopolitical, and geostrategic) are interwoven and redefined inside the 'crisis' to an impressive extent and by now to a planetary level (Avant, Finnemore \& Sell, 2010; Breslin, 2016; Carroué, 2004; Chauprade, 2007; Chavagneux, 2010; Cohen, 2008; Huntington, 2005; Kitchin, 1998; Lacoste, 2006; Lévy \& Poncet , 2008; Luttwak, 1990; Mackinder, 1904). And in this fluid environment of the global crisis (Greenspan, 2008; Kotler \& Caslione, 2009), nothing can be the same, now, with respect to the reality experienced over the past years (Adrian \& Shin, 2008; Greenspan, 2004; Laudicina \& Peterson, 2016; Prasad, Terrones, \& Kose, 2008; Stiglitz, 2003b).

The emerging new globalization can be conceived to be born and reproduced by the diverse social and economic interconnections and flows that it creates and exploits. (Figure 2) 


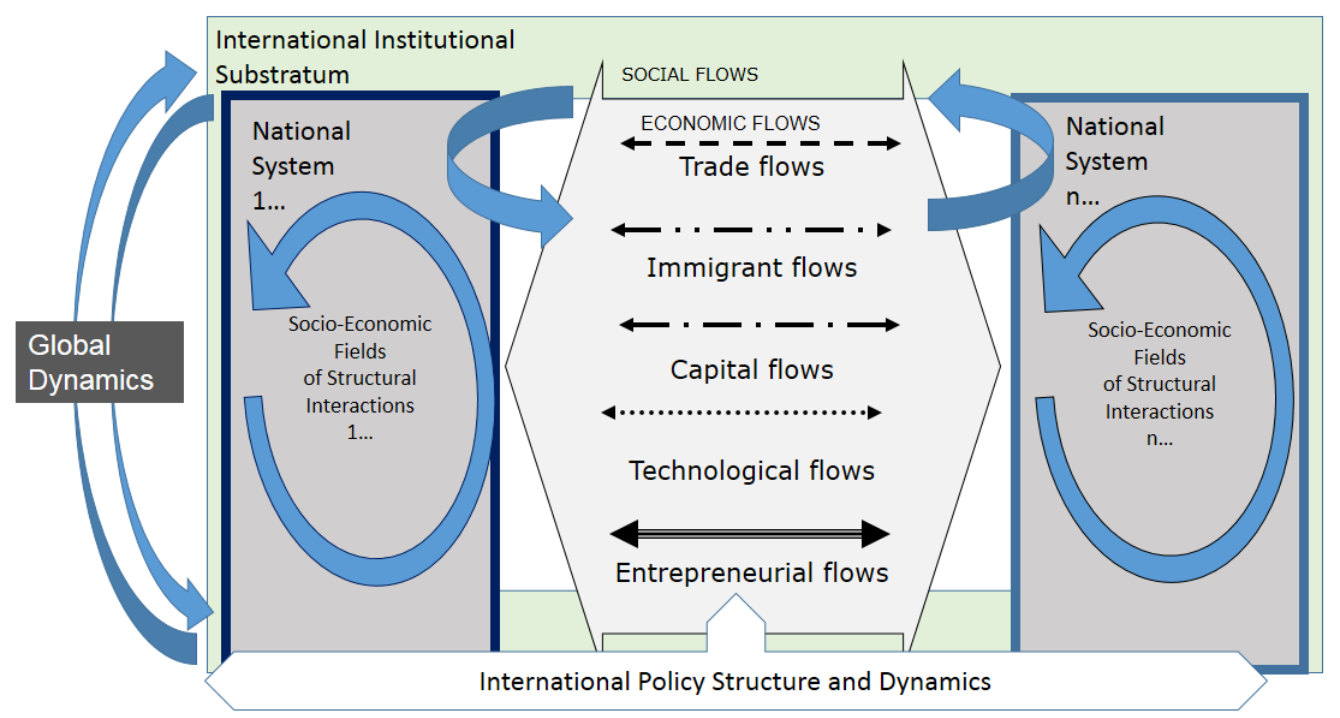

Figure 2. Global dynamics, international economic and social flows, international political structure and dynamics, and national fields of structural interactions (FSI) ${ }^{[1]}$

In this complex systemic framework, all sorts of globalizing flows and dynamics are integrated and operating. In the long run, if there were no special opportunities for the various factors of action to exploit-as well as differentiated threats - deriving from different values, fields and structures of any kind, then it would be pointless and even the very process of globalization would not exist.

\subsection{The Concept of Crisis in Economic and Business Science and the Basic Theoretical Perspectives}

In economics, although the concept of crisis is fundamental, at least since the time of Classical Political Economy, it does not cease to delimit a subject that is particularly shadowy and ambiguous (Amoore, 2002; Aydalot, 1984; Cohen, 2011; Overbeek \& van Apeldoorn, 2012; Reinhart \& Rogoff, 2009; Servet, 2010;

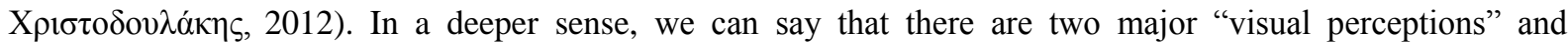
definitions of the notion of crisis: The conjunctural and the structural.

As a conjuncture, the crisis is perceived as something extraordinary, situational, as an occasional overthrow of the balance of facts/matters and ultimately as something "unnatural" but assimilable by the current system of things. Eventually, the crisis is a temporary social and economic construction that constitutes a breaking moment within an otherwise undisrupted normality (Bourdieu, 1999). The crisis arrives like a temporary fire that will eventually get extinguished and everything will go on like they used to. In this perspective, the crisis is considered to have an exceptional and unexpected character and is structured upon specific unspecified events — or a series of events — that lead to high levels of uncertainty and threat—or viewed as a threat—in relation to some high priority goals of an organization, of every level and kind.

Over the second category of perception and interpretation, in the structural, the crisis is considered a deeper situation, like something evolutionary necessary, something organic, historically irreversible, and as something that brings unavoidable changes to the system that it leans (Anderson, Arrow \& Pines, 1988; Boulding, 1970; Brian, 1989; Kuhn, 1962; Le Moigne, 1990; Lefebvre, 1968; Lugan, 2010; Prigogine \& Stengers, 1984; Prigogine \& Stengers, 1986). Hence, in this way, the crisis is captured as something endogenous, inevitable, expected, and ultimately, normal. The crisis comes, is overcome and is once more overcome, but always by taking with it the "old status" of things. Nothing then goes on like before, under the previous "regime". In this approach, the "old regime" of things necessarily collapses and is replaced by a new one (Biel \& Kho, 2009; McKeon, 1954; Popper, 2014; Postan, 1962; Spranzi, 2011). This conceptual consideration of the crisis refers to something that resembles not only the irreversible death of a system but also the inevitable birth of a new one: "the birth of the new and the death of the old" (Schumpeter, 1942). Here is the mutation which involves the irreversible changes that are placed within the logic of evolution. And here comes that situation where the rule is transformed, one class fades and another is formed (Passet, 1996).

Only in the second direction of understanding the concept of crisis, in its structural, historical and evolutionary perspective, could be recognized the structural and deeply subversive content that the crisis always conveys in every socio-economic system (Boyer \& Durand, 1998; Boyer \& Saillard, 1998; Mitroff \& Silvers, 2009; Venette, 
2003). This is also the main reason behind the growing interest in the reconstruction of economic science by some recent and old trends (Georgescu-Roegen, 2011; Rodrik, 2011; Tofler, 1970; Tofler, 1980; Tofler, 1990).

\subsection{Approaches to the Current Global Crisis and the "New Globalization"}

The global system has entered into a structural crisis and a somehow emergent remodeling, where over the next twenty to forty years, according to Wallerstein (Wallerstein, 2012), will result in a completely new system (or systems), which will either be worse than the existing ones or much better (Ahmad, 2013).

In a possible "new globalization" (El Namaki, 2017), a group of approaches tend to consider that the barriers are redeployed and become even more complex, while a lot more countries are dynamically involved and guide global growth. In this multipolar world (Pieterse, 2011), the trade growth is likely to decline, especially in commodities as well as in cross-border investments due to the protectionist forces. These rapid restructurings decentralize global supply chains, as the "computerization" which is absorbed by the new business ecosystems in a structural way is intensified. Economic policy is becoming increasingly sensitive to sudden and conjunctural changes by moving, most of the time, towards a direction in favor of nationalism and against shared global goals. In this context, there are also emerging opportunities for inter-state cooperation to institutionally change and to resolve rising threats such as cybercrime, international terrorism, and to deal with tax heavens across the globe (Bhattacharya, Khanna, Schweizer, \& Bijapurka 2017).

The impact of globalization and free trade encompasses a lot of diversity; there are always different prospects per spatial level and business sector. So, it makes sense for the individual industrial and organizational policies to have a different focus on the incentives they give for development and modernization, as long as there are differences in terms of democratic stability, of management in public and local government and of their levels of corruption (Peters, Pierre \& Randma-Liiv, 2011).

This phase of new globalization, since 2008 and about a decade earlier, represents the most expansive and technologically advanced form of globalization, with respect to all the previous ones. The prevailing analysis, however, is very often limited to mono-thematic theories of "neo-colonization" and exploitation (Milanovic, 2016), by referring especially to the poor regions of the world (Klay Kieh, 2008), and by omitting the systemic regulatory issues and the need for structural reforms. There are not, of course, few who claim that this is not a purely "new globalization" but a "new regionalization" where the complex interaction of these two phenomena is in a direction of both mutual exclusion and convergence (Hettne, Inotai \& Sunkel, 1999). As Hirst and Thompson (Hirst \& Thompson, 1999) argued, globalisation and global economic integration is organised in historical cycles that lead to decades of expansion followed by periods of contraction and regional centralisation.

According to some theorists, the new globalization is predicted to be a new regime of increasingly integrated production, while the former regime, the "old globalization", has been a phenomenon of rapid interconnection between the global and local markets (Margulesku, 2015). The diffusion of services makes the system a lot more complicated and, therefore, it is not possible to distinguish the boundaries between globalization and regionalization (Caselli, 2012; Vujakovic, 2010). The repeated appeal of the European Union's institutions-a union which represents the largest regional cooperation on the planet-is a typical example of the effort to manage globalization, already by globalization's early stages, by trying to explore and integrate relevant regulatory mechanisms (Siles-Brügge, 2012).

So, how is the global crisis going to influence the shaping of new power relations? What does it mean for the new globalization the decrease of the economic role that the US has had until recently? How is the lack of a truly global governance expected to shape the new national sovereignty (Grinin \& Korotayev, 2010)? In this context, we realize that even in the field of international relations there is no absolute shift from the national to global level (Chandler, 2009). Instead, it seems like the very ideologies of globalization get re-codified (Steger, 2013) and even more elements of complexization are introduced to the system.

There are also appearing some "new rules" for sustainable development in globalization that tend to over-protect national interests and lead to a form of a "guarded globalization" (Bremmer, 2014). Also, in the new globalization there will be no rapid financial expansion (financialization) like in the previous phase (Philip, 2012). It seems that the power and privileges of knowledge and expertise will acquire a significant strategic role (Bresser-Pereira, 2010): The cognitive capital seems increasingly as the crucial structural block for the new global economic construction.

\subsection{Structures, Behaviors, Returns, and Crisis, inside the Global System}

In the systemic concept of global dynamics we could recognize the following co-determined dimensions, under a dialectical point of view: 
* The structures that define the behavioural boundaries of the individual "players" and the behaviors that, in turn, determine the returns of each player, hence their survival and developmental potential.

* The players' returns during the crisis seem to declining drastically for a relative big number of players, by endangering at the same time their individual survival and development and also the respective potential of the whole system on a global scale. In this way, the global system reproduces its crisis.

* The global system, under certain conditions, is able to compose the necessary innovation as a way out of its crisis which, in turn, leads necessarily to the restructuring of the system's "structures" based on a successful change management, and which opens, consequently, a new cycle of development.

* Over the course of this uninterrupted process, every link of the chain determines and at the same time is determined by the underlying dynamics of the global system (Figure 3).

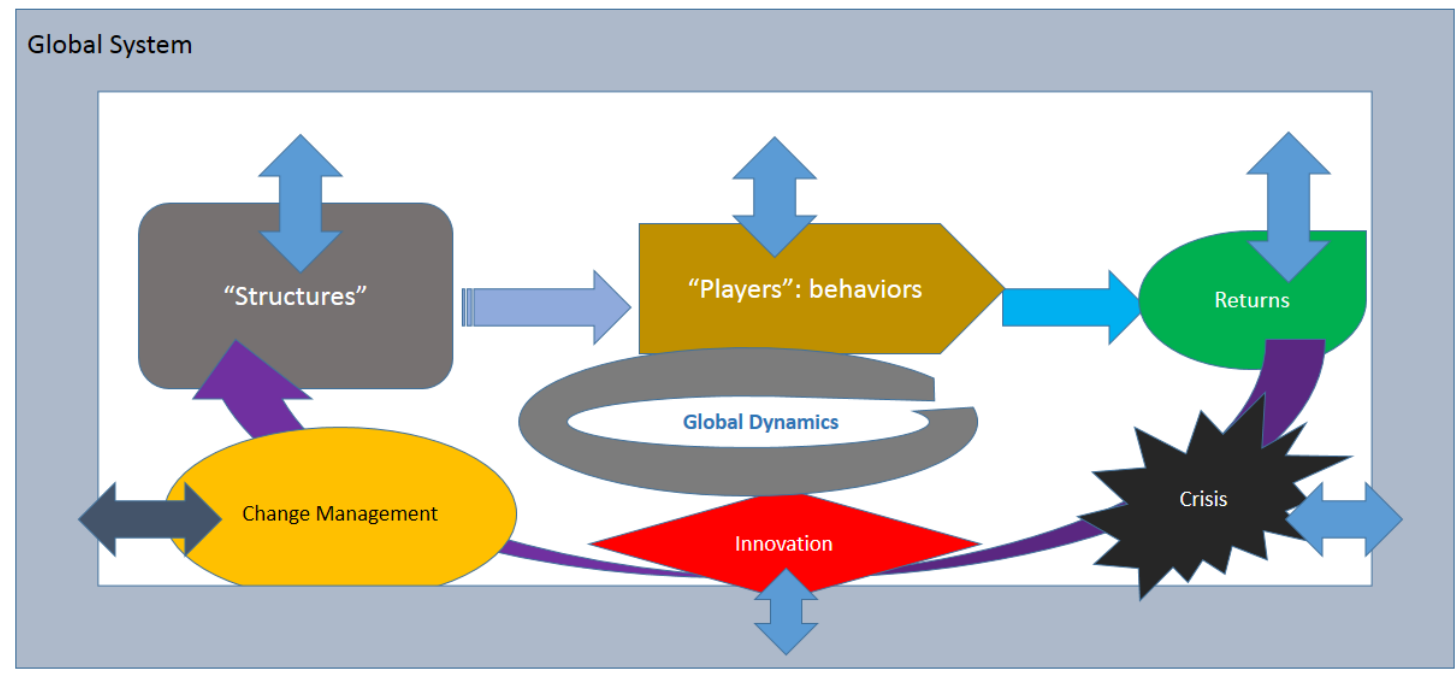

Figure 3. Structures, behaviors, returns and restructuring, inside the global system

However, besides these methodological clarifications, an effort toward a meaningful and valid understanding of globalization require a clear view of some certain key aspects and thematic challenges that the approaching new globalization carries within.

\subsection{The Challenges of Globalization Restructuring}

The public engagement concerning globalization, internationally, has almost exploded over the past thirty years. The concept of globalization has been accompanied - and still is - by passionate statements - usually against - which often lead to multiple political, social, ideological, and theoretical conflicts. And, most often, in those conflicts there is a completely paradoxical structure of "opposing camps" that is perpetuated (Abélès, 2008; Adda, 2012; Bayart, 2004; Bourg \& Papaux, 2010; Cerny, 2010; Cooper, Hughes \& De Lombaerde, 2007; Dembinski, 2008; Golub, 2011; Jaffrelot, 2008; Kunz, 2011; Lordon, 2009; Mattli \& Woods, 2009; Orléan, 2009; Palan, 2000; Rainelli, 2011; Reinert, 2008; Sinclair, 2012).

The global crisis we currently experience is, in its essence, the birth of a continuous structural process of maturity and incubation. Like in every evolutionary phase of capitalism (Michalet, 1998), the ongoing global crisis has come as a structural destabilization result of the older development regime, on a global scale. This became a reality through a long chain of events that initiated, superficially, when the sub-prime loan markets collapsed and this turbulence spread everywhere, at all levels of socioeconomic relations. It is therefore clear that and this crisis has not "fallen from the sky", it is not something exogenous. On the contrary, it "established its roots and stepped over" the structural maturity of the "previous" globalization development model: a maturity, that is, which accomplished in the last three decades, since the mid-1980s up to the mid-2000s. (Figure 4) 


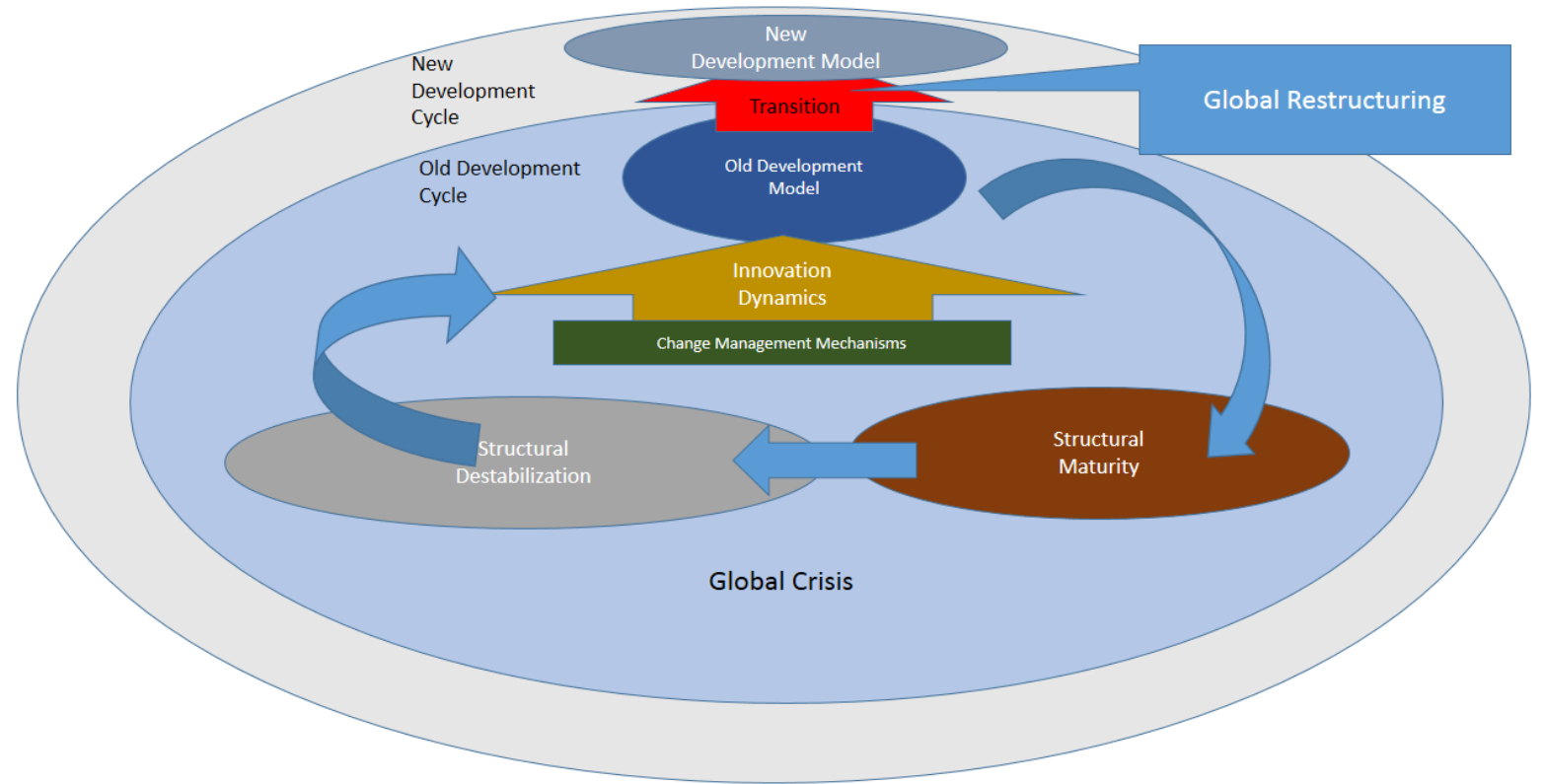

Figure 4. Global crisis and restructuring

In total terms, the formation of a "new globalization" is now called upon to give an answer to the ever intriguing questions of the evolutionary course of the global economy. The challenges which concern the rising future and the present, in our view can be distinguished in the following fundamental conflicting features of modern reality:
i. $\quad$ Poverty versus wealth
ii. Equality versus inequality
iii. Real versus financial economy
iv. Economy versus society, nature and humanity
v. Freedom versus control
vi. Uniformity versus diversity

In this basis, we consider that the shaping process of the new globalization is systematically determined by these new and sharp contradictions and challenges. In this dialectical process of globalization restructuring, there are many "diseases" and respective particular "treatments" dealing with them (B $\left.\lambda \alpha \dot{\delta} \delta o_{,}, 2017: 127-176\right)$. To sum up, therefore, some critical "disease-treatment" pairs could be briefly presented as follows:

* The best treatment for poverty in any socioeconomic system, more or less developed, is away from a superficial and temporary growth and towards a structural socioeconomic transformation focused on a long-term developmental perspective.

* The best treatment for inequality is not some "exogenous aid" but the systematic empowering of equal opportunities to development, for all people and in every society.

* The best treatment for a braking of the financial exaggerations and speculation is to create a new effective regulatory framework on a global scale.

* The best treatment to combat the narrow "economism" is to understand there can be no lasting economic success over a degraded and declining social and environmental background.

* The best treatment to strengthen human freedom is to reevaluate and restructure the role of state intervention, by focusing primarily on increasing the development potential of every socioeconomic system.

* The best treatment for preserving diversity and heterogeneity on our planet is the constant effort of every society to protect the values of tolerance and pluralism.

As far as this view is concerned, undoubtedly, the "post-crisis of globalization" world-which struggles to emerge nowadays - requires drastic reorientations and deep structural changes in order to get consolidated and 
prevail in evolutionary terms. All of those require, of course, a vast variety of innovations, and across every corner on our planet. Diagonally, through every hierarchical level, and cross-functionally, leaning on every institution and organism, either private or public, whether large and small.

It is, therefore, found that behind every major restructuring effort, there is a demand for new institutional knowledge, by having the innovation as source, and followed by the context of change management which produces that innovation: Here, ultimately, lies the essence, according to the theoretical view of this article.

\section{The Contemporary Global Dynamics of Innovation and Change Management: Toward a New Research} Model

A structural prerequisite of overtaking the global crisis is the production of innovation which is always connected to the procedures of change management that take place in every socioeconomic structure (Aghion, Bloom, Blundell, Griffith \& Howitt, 2005; Amable, Barré \& Boyer, 1997; Boyer \& Didier, 1998; Brynjolfsson \& McAfee, 2015; Carlino \& Kerr, 2015; Freeman \& Soete, 1997; Guo, 2017; Rifkin, 1997; Schumpeter, 1911; Schumpeter, 1939). However, innovation never enters our world undisturbed and entirely peacefully; it demands, most often, multiple structural sections and breaches. In reality, innovation is created through constant dialectical cross-fertilization between creativity, potential of adjustment and the composition of strategy, technology and management capabilities (Stra.Tech.Man) of human resources, groups and organizations, within the systematic framework in which they operate. (Figure 5).

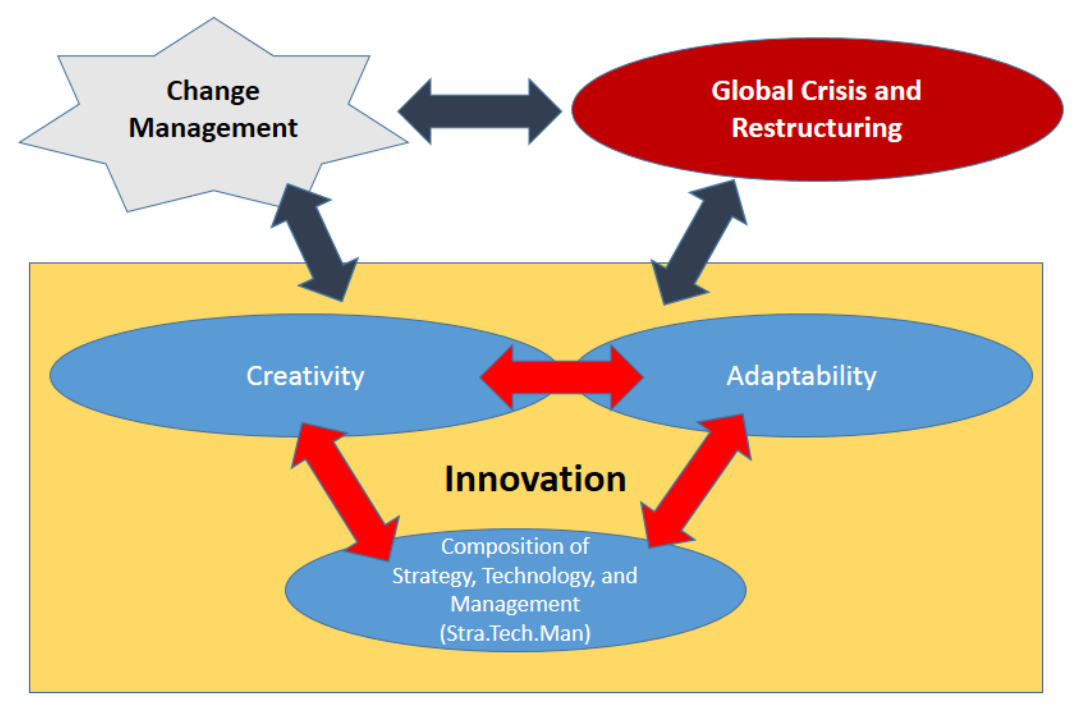

Figure 5. Innovation dynamics

In this sense, becomes clear that our world will not easily overcome in a lasting and stable way the current crisis of globalization, if it does not embrace, absorb and integrate a wide scale of innovations: The sought after restructure of the global economy seems to necessarily go through the way of systematic and effective innovation, in every level of action, private and public, economic and social, productive and consumptive, material and intangible. This, however, sought after victorious progress of innovative potential of our world, will not be achieved automatically.

It requires and it will always require, as a critical precondition, the consolidation of a complete and effective mechanism of change management in every level of structure of our contemporary world (Levin, 2012; Marquis \& Tilcsik, 2013; Marshak, 2005; Phillips, 1983; Vora, 2013). It will demand, eventually, a renewed understanding of the central dimensions of change, a gradual consolidation of a dialectical point of view in the effort of understanding the contemporary, ever-evolving reality and a new, coherent change management in terms Stra.Tech.Man, in every level of our thinking and action. (Figure 6) 


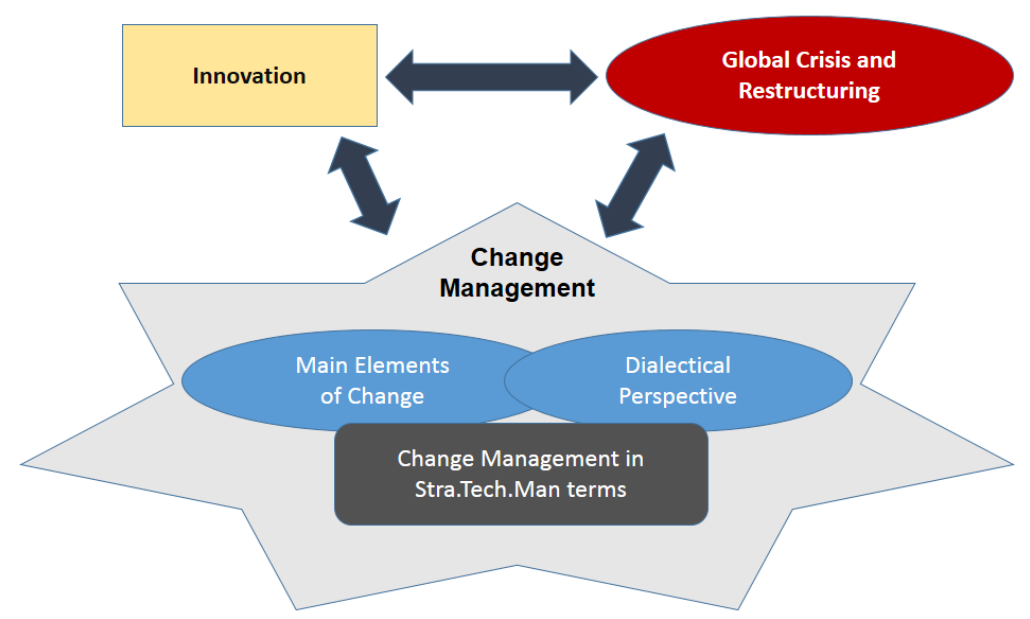

Figure 6. The challenge of change management

\subsection{Multiplicity in the Perception of Innovation}

A great number of theorists has tried to convey, in the last few decades, the content of the different point of views for innovation. These perspectives summarise a great number of various theoretical concepts deriving from different disciplines and ideological origins. We summarise some of these views in the Table below.

\begin{tabular}{ll}
\hline Theorist & Conceptual Approach on Innovation \\
\hline Peter Drucker & Innovation as a specific process of the business culture, expressed primarily at a personal level: \\
& Innovation is the specific function of entrepreneurship, whether in an existing business, a public \\
& service institution, or a new venture started by a lone individual in the family kitchen. It is the means \\
& by which the entrepreneur either creates new wealth-producing resources or endows existing \\
& resources with enhanced potential for creating wealth (Drucker, 2002).
\end{tabular}

Porter Innovation as the crucial factor of defining and altering the industrial structures, as the ultimate strategic priority and as a one-way street for the acquisition of a competitive advantage. More specifically, Porter presents innovation as the result of unusual effort. The firm that successfully implements new or improved ways of competing is the one that doggedly pursues its approach, often in the face of obstacles. The strategy is the personal crusade of an individual or group. As a consequence, innovation often results from pressure, necessity, or even adversity. The fear of loss often proves more powerful than the hope of gain (Porter, 1990).

Nonaka and Kenney Inherently, innovation is the process by which new information emerges and is concretized in a product that meets human needs. The healthy firm is a negative-entropy system which constantly creates new order and structure in its struggle to survive and grow. (...) To remain competitive any firm must constantly be creating new strategies, new products, and new ways of manufacturing, distributing and selling (Nonaka \& Kenney, 1991).

Rogers An innovation is an idea, practice, or object that is perceived as new by an individual or other unit of adoption. It matters little, so far as human behavior is concerned, whether or not an idea is "objectively" new as measured by the lapse of time since its first use or discovery. The perceived newness of the idea for the individual determines his or her reaction to it. If the idea seems new to the individual, it is an innovation (Rogers, 1982).

Rosenfeld Innovation involves more than turning out high-tech gadgets, and innovators are complex human beings of different backgrounds and all types. Unfortunately, innovation has hit a wall in the workplace because the human component has frequently been neglected. Organizations focus too much on the mechanics of innovation and not enough on the underlying people-based principles. To promote innovation, leaders must first understand what drives it: people (Rosenfeld, 2008).

Gets and Robinson A business is creative when its workers produce something new and probably useful without having been taught or guided by anyone else. For them, the material evidence of creativity are the upgrades-changes to what has already been accomplished while the innovations represent something entirely new for the business. Many good companies have fallen prey to 'Innovate or Die' mantra, skipped over the foundations of progress-customer-focused processes and managing their employees' spontaneous ideas - and jumped straight into building the penthouse - the layer of innovation capability. They have paid the price of not taking care of the foundation first. It is always fun in the penthouse, but the fun will not last long if it is built on moving sand (Getz \& Robinson, 2003).

\begin{tabular}{ll}
\hline Narayanan (2001) & "Innovation refers both to the output and the process of arriving at a technologically feasible solution \\
to a problem triggered by a technological opportunity or customer need" (Narayanan, 2001).
\end{tabular}

This very short summary of definitions on innovation is enough to realize the multiplicity of the term. Despite the same notion of innovation can be perceived in many ways, it is clear that innovation can derive only from 
creativity and business development that, in turn, is the end result of strategy and organizational sustainability. However, the organic character of innovation is omitted by the traditional economic and administrative approaches and, as a result, the systemic and strategic response of organizations to external crises and environmental changes lacks analytical and practical efficiency. Businesses ought to constantly adjust themselves within complex, almost chaotic, conditions and innovation by itself is the response- and also the catalyst - to all the crises.

\subsection{Contemporary Approaches of Innovation and Change Management within the Crisis}

The social changes, chaotic and unpredictable as they may be, always involve a systematic personality. Without the understanding of this systematic personality, nothing can interpret the structural continuance and change to the human and organizational behaviors (Burns, 2007).

Although, of course, the gradually deeper specialization of the economic science in matters of organization, few approaches are able to shed a light in the correlation between the three forces: the crisis, the innovation and the change management. In the direction of a "neo-schumpeterian" approach (Kleinknecht, 1987), we could claim that the crisis is not so much a result of a "dry" and intangible financialization (Beck, Chen, Lin \& Song, 2016), but it is about a phenomenon born from the business evolution and innovative potential. It is a dialectical readjustment of the old order of things that guides the system (the global economy in this instance) towards a new, different from the past, evolution.

In the majority of contemporary scientific articles, however, the approach of the global crisis is simplistically identified through the consequences of the financial globalization (Hausman \& Johnston 2014; Sánchez, 2010; Sveiby, 2012), sometimes carrying a positive sign, and most times, a negative one. Certainly any narrow financial mechanisms for facing the crisis are not sufficient to provide effective solutions, because a stimulation of active demand, within the ethnocentric framework, is unfeasible due to the current accomplished interspatial complexity of the global economy. On the other hand, the exclusive focus on the relational and human resources (Melé, Argandoña \& Sanchez-Runde, 2011; Sultanova \& Chechina, 2016) shifts away from the ultimate target of a complete developmental agenda in economic policy, as it leaves out crucial characteristics of the system that led to the need of an advanced human capital.

Entering, therefore, into the deeper characteristics that consist the economic activity, it is important to report an indicatory relationship between the global crisis and the innovative results of businesses and their consequent developmental courses. A recent research (Paunov, 2012) proves that for the years 2008-2009 in eight countries of South America, crisis led a number of companies to pause their innovative projects. Businesses that had access to public funding were less likely to give up, while newer companies and businesses-suppliers towards multinational foreign counterparts there were those that presented halting of their activities at a more usual rate.

This fact indicates not only the lack of targeting in economic policy by the majority of the emerging and medium level of development nations towards the methods of enhancement of local development (Vlados, Deniozos, \& Chatzinikolaou, 2018), but also the struggle in establishing mechanisms of change management within the businesses themselves. To achieve all the above, it is important to penetrate those forces that determine the operation of the business and, as a result, the total dynamics that is diffused within the global economic system: The structural triptych of strategy technology and management.

\subsection{The Innovative Environment and the Dynamics of Strategy, Technology and Management (Stra.Tech.Man)}

In this paper we propose a conceptual model that bring together the conditions of macro-economic and systemic crisis with the internal, organisational and strategic responses. We have argued so far that crises constitute moments of cosmological collapses (Weick, 1999) but they also constitute moments of deep thinking about the business models and should be linked with intensive innovation.

The main point of this present work, consists of the finding that although many innovations seem to be pushed authoritatively towards the organizational cell of the procedure, by one of the three forces Stra.Tech.Man - either by strategy, or technology, or management - there can never be any innovation completed in the inside of any organization without going through and transform synthetically all of its three main structural spheres (Vlados \& Katimertzopoulos, 2017). (Figure 7) 


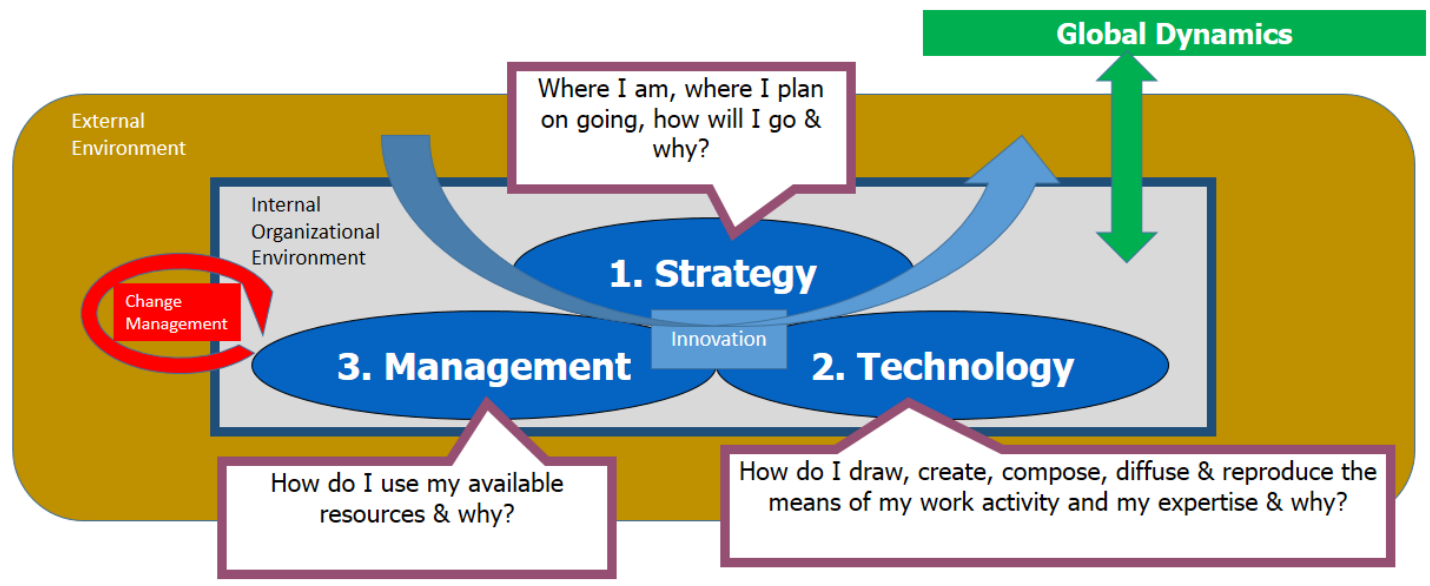

Figure 7. The evolving core of business, innovation, change management, and global dynamics

All these three dimensions of the organizational Stra.Tech.Man always converge and evolve. All the dimensions together get reorganized and coordinated necessarily in the dynamics of the global environment and are evolutionary reinserted in the innovative game. This is necessary and unescapable. And all these together lead to the constant evolving of the organization itself in terms Stra.Tech.Man and of its structural external environment as well. (Figure 8)

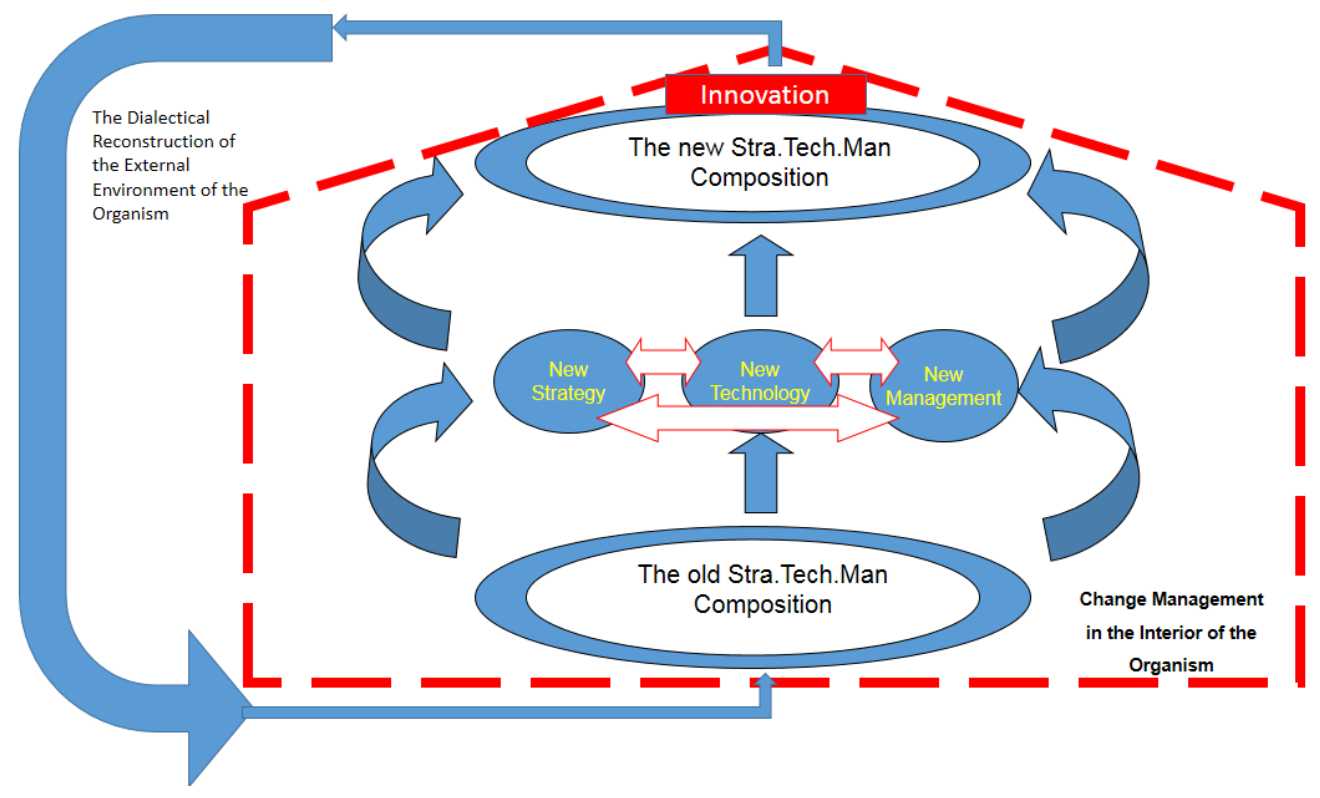

Figure 8. The reproduction of the innovative dynamic of the business in terms Stra.Tech.Man and the constant restructure of its external environment

Within a world that tends to be more "open" and interactive, the borders of organizations, of any type and level, they become more and more porous and vague. In this contemporary reality the notion of "innovative environment" (milieu innovateur) (Aydalot, 1986), in every level of space-national, international, regional and local-seems to be getting progressively critical importance. In practice, we can perceive the innovative environment as a spatially established socioeconomic composition of multiple knowledge, decision and action, which is dialectically opened externally, towards its environment. "Gives and takes", incorporates and diffuses ideas, expertise, practice, values, and methods of operation, rules and "relational capital". It is about, in practice, an environment "tied", always, with a community of carriers/perpetrators and their available resources, human, cognitive, informative and material. It is not a "closed box" but, instead, it is a complicated system in a constant interaction and intellectual evolution with its wider external environment.

Essentially, every organization in its core is a receiver and, at the same time, a transmitter of elements, data and actions within its operational ecosystem in which it is based and evolved. And in that way, the composition 
Stra.Tech.Man which is achieved by any organization depends directly upon its structure and the dynamics of the ecosystem in which it is based and evolved and which, in turn, participates and contributes, more or less in the utterance of the global dynamics. (Figure 9)

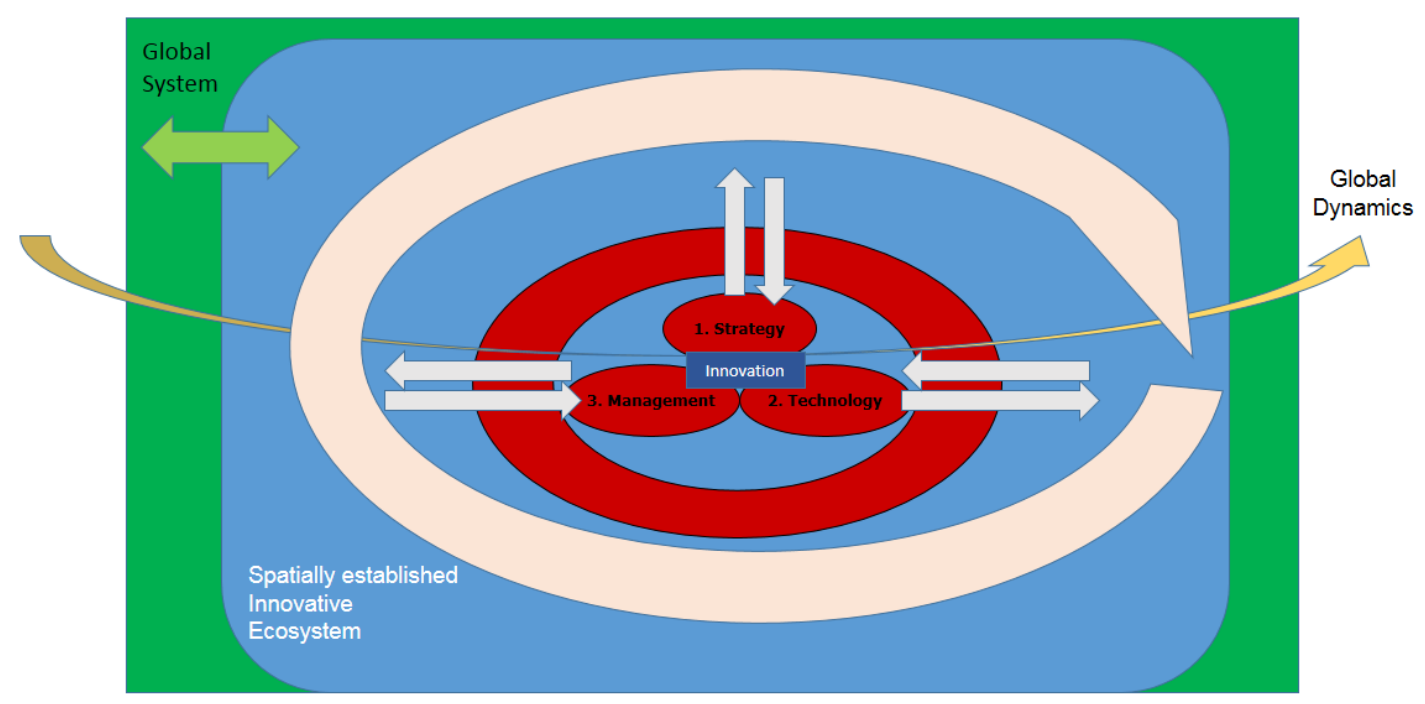

Figure 9. Spatially established innovative environment, composition Stra.Tech.Man and global dynamics

In practice, every organization draws data with which it develops the strategic, technological and managemental "arsenal" and, at the same time, channels towards its environment strategic, technological and managerial components and resources. It "inhales" strategic, technological and managemental resources, it synthesizes it, internally, in its way, trying then to "exhale" it as innovation. And, of course, cohabits and develops articulating - and restructuring without interference - its necessary structural relations that overtake its plain market transactions. And through this notion every organization is a birth of the innovative wealth-or poverty — of the same "space" that hatches and hosts it while, at the same time, contributes ceaselessly with its presence and action in the structure of the innovative wealth or the poverty of that space (the "space" can be perceived in every level of space: national, international, regional or local).

The innovative resources Stra.Tech.Man of every organization "do not just fall of the sky". The fauna (organizations) of the "ecosystem" directly depend upon the flora that surrounds it and "breeds" it (institutions, regularities, total socioeconomic framework). Likewise, of course, the "flora" of every innovative ecosystem is influenced directly by the way the various "living organisms" act within its evolving interior.

\subsection{The Renewal of the Mechanisms of Change Management, in Every Level of Action}

The problems in change management do not constitute an establishment, something settled and reassured scientific field so there can be clear and predefined theoretical limits and clear methodological preconditions in its approach. There is no "general theory" on the subject and there is no agreement over a paramount example. On the other hand, not only the theory but also the practice of the change management seems to result, in our time, from the convergence and interference of a big number of branches of the social studies and various notional interdisciplinary traditions. Even if that is where the power and the charm may lie, the investigation of its theoretical foundation and potential does not ceases to make up for a difficult case (Burnes, 2009: 258-261).

Change, according to the point of view we suggest, is a procedure that materializes ceaselessly for the entire life and operation of the organization, whether it desires so or not. With the simplest definition possible, change is the procedure of modification of the way in which an individual, a team or an organization acts as a group by going through a set of ways of action and behavior to another one, transforming its performance and effectiveness.

The forces that influence the change are always, simultaneously, both external and internal in a business. The external forces are about its direct micro-environment (market, competition, suppliers, franchises and supplementary products, distribution networks etc.) as well as its macro-environment (legislation, society, technology, environment, economy etc.). The internal forces come from the internal strategic mechanisms, its technological structure and from the special nature of authority and administration at its interior and human resources. 
In the international bibliography of the subject, what prevails is the distinction of change in the base of three distinct models:

- The incremental model of change (Burnes, 2009: 254), in which change becomes perceived as a procedure through which the unique pieces of an organization arrange incrementally and uniquely a problem, facing one target at a time. With managers meeting the needs of the changing internal and external environments. One step at a time, through the progress of time, organizations transform and evolve (Miller, 1984).

- The model of interrupted balance of the organizational transformation (punctuated equilibrium) (Burnes, 2009: 255) which perceives organizations to be evolving through relatively big periods of time of stability (stability periods) in the main models of their activity and which get interrupted by relatively small "outbreaks" of fundamental change (revolutionary periods). Those revolutionary time periods, the "times of explosion", essentially, disrupt the installed motives of activity and re-establish the foundations for the new periods of balance (Tussman \& Romanelli, 1994).

- The model of constant transforming of change (continuous) (Burnes, 2009: 255-258) claims that in order to survive, organizations must develop their ability to constantly change themselves, at a stable and continuous rate, every moment and ceaselessly (Brown \& Eisenhardt, 1997).

Under these conditions, therefore, is born inevitably the reaction to change. It is about that force which appears in individuals, groups or even entire organizations and which tends to refuse, obstruct, limit or even completely cancel the magnitude of the necessary changes. In practice, conflicts always brings about a special content in terms of personal, team, sectional and total organizational and intra-organizational dimensions.

\subsection{The Five Steps of the Stra.Tech.Man Viewpoint in Change Management}

The contemporary change manager, in every type of organization, according to the viewpoint we present, owes to clarify the main "physiological" targets of change, before any action, in terms Stra.Tech.Man. In detail, every organization owes to conceive and understand the unique "physiological" advantages and disadvantages, based in the composed Stra.Tech.Man viewpoint and which opens up at the same time, space for special opportunities and threats that they face in the contemporary, uniquely demanding and labyrinthian, global economy. The more critical problems that the organization faces and those that put a barrier in the effective change management are finally at its physiological core. That is, they are born and reproduced through the total evolving dimensions.

- In its complete strategy

- Its complete technology

- Its complete management

This is the reason why, in our perception of change management, we firmly move away from the analytic theory which perceives social organizations of every kind linearly and as static mechanisms, and we move, unreservedly, towards an understanding that perceives them in a dialectical way (Cassin, 2004; Corbett \& Connors, 1998; Fox, 2005; Kaufman, 1966; Lenin, 1976; Popper, 2015; Sartre, 1984), like living and evolving organisms. As a result, we remain convinced that every effort of managing change, inside any organization, must primarily take under consideration its "living" nature, inside its ever evolving "living", external environment.

In this way and on these conceptual foundation, we can formulate five phases (Figure 10) of change management under the Stra.Tech.Man viewpoint we propose, as an endeavor of composing the approaches concerning management change. Specifically, we suggest those five steps of change management under the Stra.Tech.Man viewpoint as a constant cycle of five perpetually repeated steps, which are destined to ensure: (i) the successful strategic transformation, (ii) the successful technological transformation, (iii) the successful managerial transformation, (iv) the successful innovative composition and (v) the successful assimilation of change and the constant, adaptive variation of organization. 


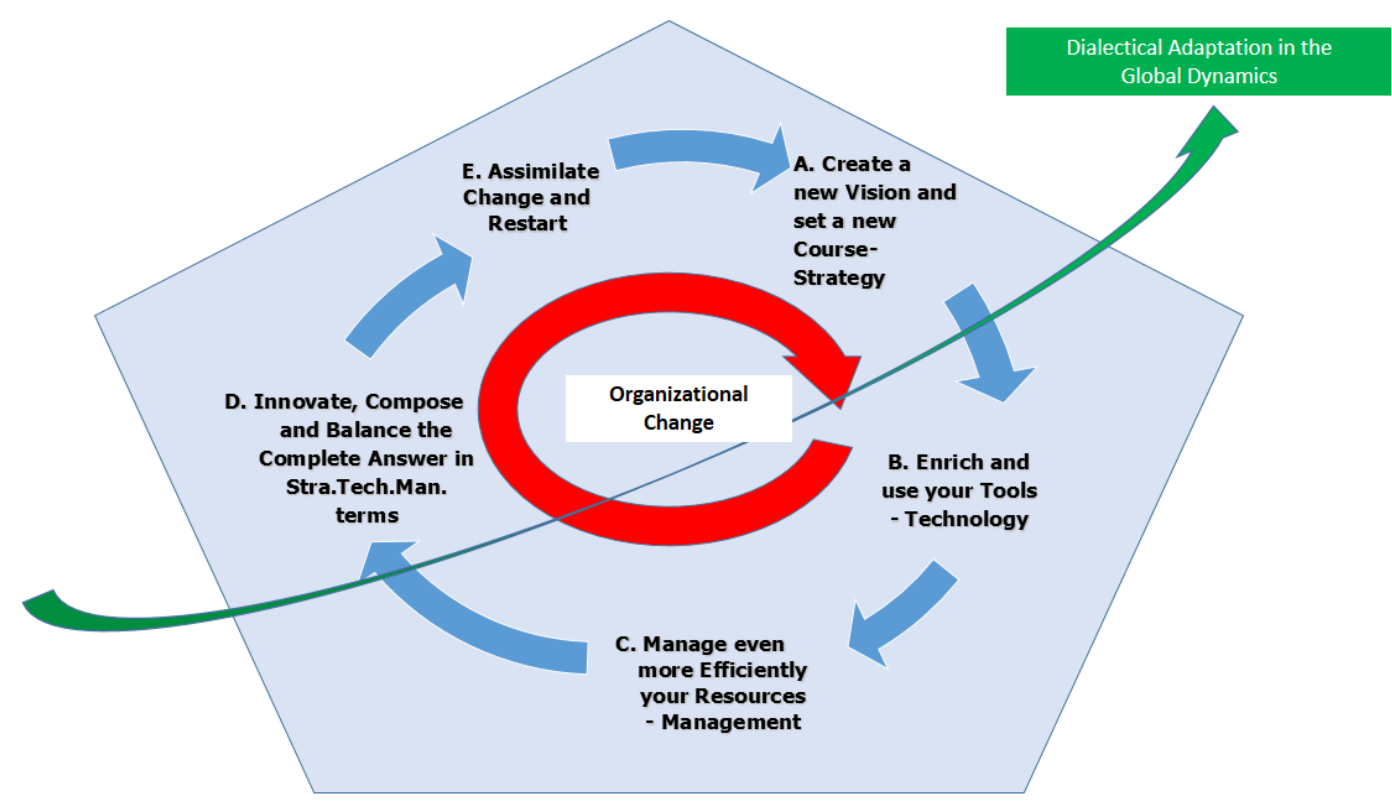

Figure 10. The five steps of change management through the Stra.Tech.Man approach and the dialectical adjustment of organizations in the global dynamic

All these previous steps, in each individual link, we assess they have to be materialized, always, through an open, evolving, dialectical spirit. Otherwise, they cannot fulfill the potential of change management that every organization holds.

\section{Conclusive Comments and Limitations: Towards a New Economic-Political Synthesis for the Overcoming of the Crisis at a Global Level. The Direction of a Realistic Innovative Liberalism}

The idiosyncratic track of the current crisis of globalization seems to be imprinted by now, directly, in the deepest level of the socioeconomic evolution of every region and every agent of action on the planet. It penetrates and dissects the real life of every individual, group and entire organization, their plans and actions of every kind.

The successful innovation on behalf of the various social organizations, as well as the structure and operation of their management change mechanisms cannot be fulfilled under "institutional gap". Entirely differently, the total institutional substratum, in every level of structure and operation constitutes, simultaneously, both the engine and the institutional receiver of the global dynamics of the sought-after restructure.

In conclusion, the global restructuring process will end up in benefiting the socioeconomic development only when a new global structural triptych will get effectively combined and established: toward a new model of ideological and political understanding of the contemporary global developments. (Figure 11) 


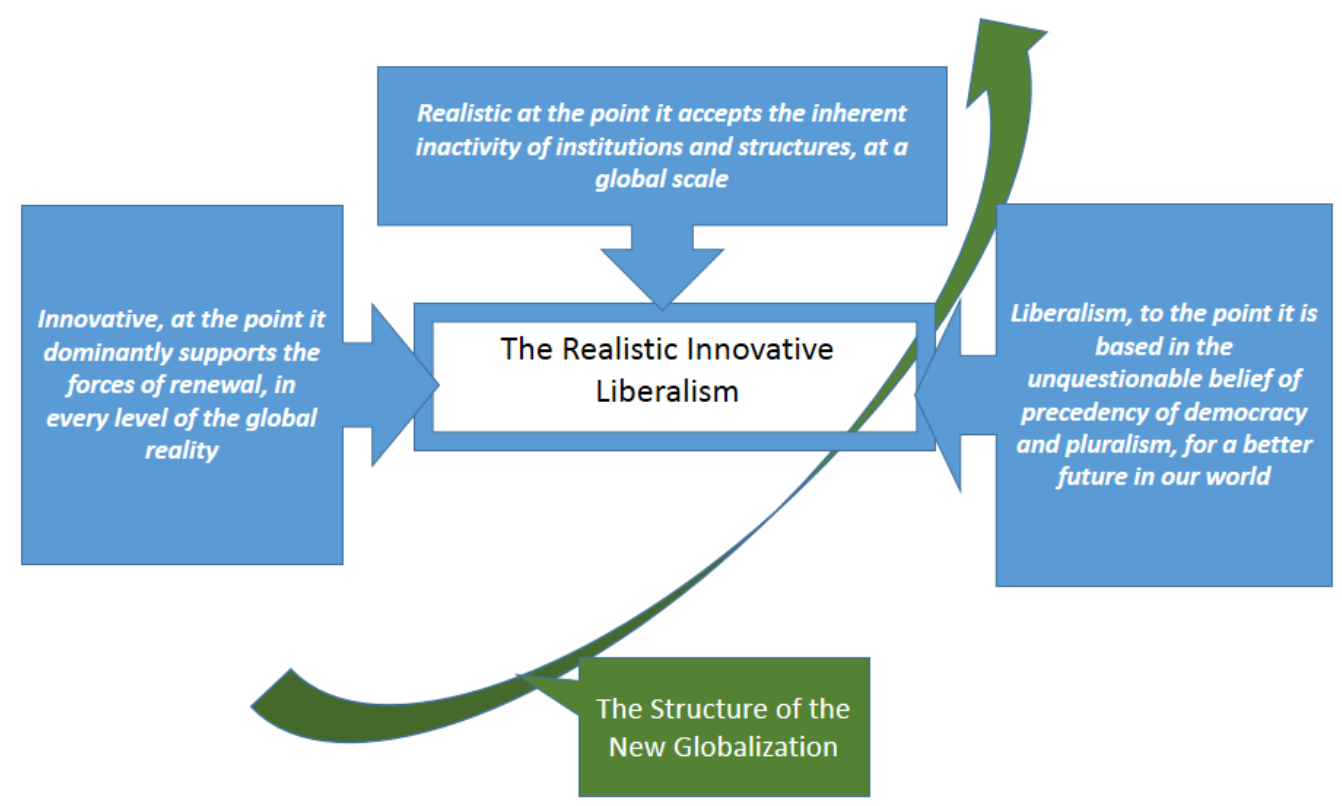

Figure 11. Realistic innovative liberalism and the structure of the new globalization

Thus, for building an effective structural triptych of a "realistic innovative liberalism" first of all a renewed way of viewing global dynamics is needed. A view that achieves to give the appropriate emphasis to all three components and fertilize them in practice.

- Realistic, at the level it accepts the inherent inactivity of institutions and structures, in global level.

- Innovative, at the level it supports dominantly the forces of renewal, in every operating level of the global reality.

- Liberalism, in the level it is based in the undisputed belief of the precedency of freedom, democracy and pluralism, for a better future in our world.

Over the course of a world which constantly reminds us of its increasing uncertainty, the combination of an ideological-political thought characterized by a structural link between realism, innovation and the creation of favorable conditions for liberal action can be the decisive criterion for integrating all those actors that are called upon to shape a sustainable new model of development; that is the new globalization. The limitations of that perspective are, of course, of theoretical and practical reach. Ideological and methodological repositions and policy restructurings will be definitely required for such kind of perspective to flourish; and over multiple levels of understanding and, of course, on a global scale.

\section{References}

Abélès, M. (2008). Anthropologie de la globalisation. Paris: Payot.

Adda, J. (2012). La mondialisation de l'économie. Paris: La Découverte.

Adrian, T., \& Shin, H. S. (2008). Liquidity, monetary policy, and financial cycles. Current Issues in Economics and Finance, 14(1).

Aghion, P., Bloom, N., Blundell, R., Griffith, R., \& Howitt, P. (2005). Competition and innovation: An inverted-U relationship. The Quarterly Journal of Economics, 120(2), 701-728. https://doi.org/10.1093/qje/120.2.701

Aglietta, M. (1998). Le capitalisme de demain: Notes de la Fondation Saint-Simon. Paris: Novembre.

Aglietta, M. (2008). La crise: Pourquoi en est-on arrivé là? Comment en sortir?. Paris: Michalon.

Aglietta, M., \& Brender, A. (1984). Les métamorphoses de la société salariale: La France en projet. Paris: Calmann-Lévy.

Aglietta, M., \& Orléan, A. (1982). La violence de la monnaie. Paris: PUF. 
Aglietta, M., \& Orléan, A. (2002). Monnaie (La): Entre violence et confiance. Paris: Odile Jacob.

Aglietta, M., \& Rebérioux, A. (2004). Les dérives du capitalisme financier. Paris: Albin Michel.

Ahmad, A. (2013), New age globalization: Meaning and metaphors. New York: Palgrave Macmillan. https://doi.org/10.1057/9781137319494

Amable, B. (2000). Institutional complementarity and diversity of social systems of innovation and production. Review of International Political Economy, 7(4), 645-687. https://doi.org/10.1080/096922900750034572

Amable, B. (2002). La diversité des systèmes d'innovation et de production dans les annés 90. In P. Touffut, Innovation et Croissance, ouvrage collectif. Paris: Albin Michel.

Amable, B., Barré, R., \& Boyer, R. (1997). Les systèmes d'innovation à l'ère de la globalisation. No. 50.003 AMA.

Amoore, L. (2002). Globalisation contested: An international political economy of work. Manchester: Manchester University Press.

Anderson, P. W., Arrow, K., \& Pines, D. (1988). The economy as an evolving complex system. Boulder, Colorado: Westview Press.

Aoki, M. (2001). Toward a comparative institutional analysis. Cambridge, MA: MIT Press.

Artus, P. (2001). La nouvelle économie. Paris: La Découverte.

Artus, P., \& Virard, M. P. (2015). Croissance zéro, comment éviter le chaos? Paris: Fayard.

Avant, D. D., Finnemore, M., \& Sell, S. K., (2010). Who governs the globe?. Cambridge, UK: Cambridge University Press. https://doi.org/10.1017/CBO9780511845369

Aydalot, P. (1984). Crise et espace. Paris: Economica.

Aydalot, P. (1986). Milieux innovateurs en Europe. Paris: GREMI.

Bayart, J. F. (2004). Le gouvernement du monde. Une critique politique de la globalisation. Paris: Fayard.

Beck, T., Chen,T., Lin, C., \& Song, F. M. (2016). Financial innovation: The bright and the dark sides, HKIMR Working Paper No.05/2012, 72, 28-51.

Benassy, J. P., Boyer, R., Gelpi, R. M., \& Lipietz, A. (1977). Approches de l'inflation: L'exemple français. Paris: CEPREMAP.

Bhattacharya, A., Khanna, D., Schweizer, C., \& Bijapurka, A. (2017, April 25). The new globalization: Going beyond the rhetoric. Retrieved from: https://www.bcg.com/en-gr/publications/2017/new-globalization-going-beyond-rhetoric.aspx

Biel, R., \& Kho, M. J. (2009). The issue of energy within a dialectical approach to the regulationist problematique. Recherché \& Régulation Working Papers: RR Série ID 2009-1.

Billaudot, B. (1996). L'ordre économique de la société moderne: Un réexamen de la théorie de la régulation. Paris: Editions L'Harmattan.

Billaudot, B. (2001). Régulation et croissance: Une macroéconomie historique et institutionnelle. Paris: Editions L'Harmattan.

Boltansky, L., \& Chiapello, È. (1999). Le nouvel esprit du capitalisme. Paris: Gallimard.

Boulding, K. E. (1970). Economics as a science. New York: Mc Graw Hill.

Bourg, D., \& Papaux, A. (2010). Vers une société sobre et désirable. Paris: Presses Universitaires de France. https://doi.org/10.3917/puf.brg.2010.01

Boyer, R. (1986). La théorie de la régulation: Une analyse critique. Paris: La Découverte.

Boyer, R. (2002). La croissance, début de siècle: De l'octet au gène. Paris: Bibliothèque Albin Michel Économie.

Boyer, R. (2004). Une théorie du capitalisme est-elle possible?. Paris: Odile Jacob.

Boyer, R., \& Didier, M. (1998). Innovation et croissance. Paris: La Documentation française.

Boyer, R., \& Durand, J. P. (1998). L'après-fordisme. Paris: Syros.

Boyer, R., \& Freyssenet, M. (2000). Les modèles productifs. Paris: La Découverte.

Boyer, R., \& Saillard, Y. (eds.) (1998). Théorie de la régulation: L'état des savoirs. In Annales: Histoire, Sciences 
Sociales (pp. 693-694), L'état des savoirs.

Braudel, F. (2014). La dynamique du capitalisme. Paris: Flammarion.

Bremmer, I. (2014, January-February). The new rules of globalization. Harvard Business Review: International Business.

Brender, A., \& Pisani, F. (2009). La crise de la finance globalisée. Paris: La Découverte.

Breslin, S. (2016). China and the global political economy. New York: Springer.

Bresser-Pereira, L. (2010). The global financial crisis and a new capitalism?. Economics Working Paper Archive wp_592. https://doi.org/10.2753/PKE0160-3477320401

Brian, W. A. (1989). Positive feedbacks in the economy. Scientific American, 1, 92-99.

Brown, S. L., \& Eisenhardt, K. M. (1997). The art of continuous change: Linking complexity theory and time-paced evolution in relentlessly shifting organizations, Administrative Science Quarterly, 1-34. https://doi.org/10.2307/2393807

Brynjolfsson, E., \& McAfee, A. (2015). Le deuxième âge de la machine: Travail et prospérité à l'heure de la révolution technologique. Paris: Odile Jacob.

Burnes, B. (2009). Managing change: A strategic approach to organisational dynamics ( $5^{\text {th }}$ ed.), Harlow: Pearson Education Limited.

Burns, D. (2007). Systemic action research: A strategy for whole system change. Bristol: Policy Press.

Carlino, G., \& Kerr, W. R. (2015). Agglomeration and innovation. Handbook of Regional and Urban Economics, 5, 349-404. https://doi.org/10.1016/B978-0-444-59517-1.00006-4

Carroué, L. (2004). Géographie de la mondialisation. L'Information Géographique, 68(2), 191. Retrieved from: www.persee.fr/doc/ingeo_0020-0093_2004_num_68_2_2945_t1_0191_0000_3

Caselli, M. (2012). Trying to measure globalization: Experiences, critical Issues and perspectives. Dordrecht, Heidelberg, London, New York Springer. https://doi.org/10.1007/978-94-007-2807-3

Cassin, B. (ed.) (2004). Vocabulaire européen des philosophies: Dictionnaire des intraduisibles. In Histoire épistémologie langage (Vol 26, p. 181). Paris: La linguistique baltique.

Cerny, P. G. (2010). Rethinking world politics: A theory of transnational neopluralism. Oxford, UK: Oxford University Press. https://doi.org/10.1093/acprof:oso/9780199733699.001.0001

Chandler, D. (2009). The global ideology: Rethinking the politics of the 'global turn'. International Relations, 23(4), 530-547. https://doi.org/10.1177/0047117809350989

Chauprade, A. (2007). Géopolitique: Constantes et changements dans l'histoire. Paris: Ellipses Marketing.

Chavagneux, C. (2010). Economie politique internationale. Paris: La Découverte.

Chavagneux, C. (2011). Une brève histoire des crises financières: Des tulipes aux subprimes. Paris: La Découverte.

Chavance, B. (2012). L'économie institutionnelle. Paris: La Découverte.

Cohen, B. J. (2008). International political economy: An intellectual history. New Jersey: Princeton University Press.

Cohen, D. (2011). La mondialisation et ses ennemis. Paris: Pluriel.

Cooper, A. F., Hughes, C. W., \& De Lombaerde, P. (2007). Regionalisation and global governance: The taming of globalisation?. UK: Routledge.

Corbett, E. P., \& Connors, J. R. (1998). Classical rhetoric for the modern student ( $4^{\text {th }}$ ed.). Oxford, UK: Oxford University Press.

Coriat, B. (1979). L'atelier et le chronomètre: Essay sur le taylorisme, le fordisme et la production de masse. Paris: Christian Bourgois.

Coriat, B. (1994). L'atelier et le robot: Essai sur le fordisme et la production de masse à l'âge de l'électronique. Paris: Christian Bourgois Editeur.

Coriat, B., Petit, P., \& Schmeder, G. (2006). The hardship of nations: Exploring the paths of modern capitalism. Edward Elgar Pub. 
Curien, N. (2000). Economie des réseaux. Paris: La Découverte.

Delorme, R., \& André, C. (1983). L'état et l'économie. Paris: Seuil.

Dembinski, P. (2008). Finance servante ou finance trompeuse. Paris: Desclée de Brouwer.

Dobbs, R. (2015). Debt and (not much) deleveraging. McKinsey Global Institute, 136.

Drucker, P. (2002). The discipline of innovation. Harvard business review, 80, 95-104.

Dulong, D. (2012). Sociologie des institutions politiques. Paris: La Découverte.

El Namaki, M. (2017). Neo-globalization: Premises, processes and the future. Scholedge International Journal of Business Policy \& Governance, 4(7), 71-77. https://doi.org/10.19085/journal.sijbpg040701

Esping-Andersen, G. (1990). The three worlds of welfare capitalism. New Jersey: Princeton University Press.

Esping-Andersen, G. (1999). Social foundations of postindustrial economies. Oxford, Uk: Oxford University Press. https://doi.org/10.1093/0198742002.001.0001

Fox, M. (2005). The accessible hegel. Amherst: Humanity Books.

Freeman, C., \& Soete, L. (1997). The economics of industrial innovation. East Sussex: Psychology Press.

Gadrey, J., \& Jany-Catrice, F. (2012). Les nouveaux indicateurs de richesse. Paris: La Découverte.

Georgescu-Roegen, N. (2011). From bioeconomics to degrowth: Georgescu-Roegen's 'new economics' in eight essays. London: Routledge.

Getz, I., \& Robinson, A. (2003). Innovate or die: Is that a fact? Creativity and Innovation Management, 12(3), 130-136. https://doi.org/10.1111/1467-8691.00276

Golub, P. (2011). Une autre histoire de la puissance américaine. Paris: Seuil.

Greenspan, A. (2004). Risk and uncertainty in monetary policy. American Economic Review, 94(2), 33-40. https://doi.org/10.1257/0002828041301551

Greenspan, A. (2008). The age of turbulence: Adventures in a new world. London: Penguin Books.

Grinin, L., \& Korotayev, A. (2010). Will the global crisis lead to global transformations? The coming epoch of new coalitions. Journal of Globalization Studies, 1(2), 166-183.

Guo, Z. Y. (2017). How information is transmitted across the nations? An empirical investigation of the US and Chinese commodity markets. Global Journal of Management and Business Research, 17(1), 1-11. https://doi.org/10.2139/ssrn.3013797

Hausman, A., \& Johnston, W. J. (2014). The role of innovation in driving the economy: Lessons from the global financial crisis. Journal of Business Research, 67, 2720-2726. https://doi.org/10.1016/j.jbusres.2013.03.021

Hettne, B., Inotai, A., \& Sunkel, O. (1999). Globalism and the new regionalism. London: Macmillan. https://doi.org/10.1007/978-1-349-27268-6

Hirst, P., \& Thomspon, G. (1999). Globalization: Frequently asked questions and some surprising answers. Globalization and Labour Relations, 36-56.

Huntington, S. P. (2005). Le choc des civilisations. Paris: Odile Jacob.

Jaffrelot, C. (2008). L'enjeu mondial: Les pays émergent., Paris: Les Presses de Sciences Po.

Kaufmann, W. A. (1966). Hegel: A reinterpretation. New York: Doubleday.

Kitchin, R. (1998). Cyberspace: The world in the wires. New York: John Wiley \& Sons.

Klay Kieh, G. (2008). Africa and the new globalization. Farnham, UK:Ashgate Publishing.

Kleinknecht, A. (1987). Innovation patterns in crisis and prosperity: Schumpeter's long cycle reconsidered. New York: Springer.

Kotler, P., \& Caslione, J. (2009). Chaotics: The business of managing and marketing in the age of turbulence. New York: AMACOM.

Kuhn, T. (1962). The structure of scientific revolutions. Chicago: The University of Chicago Press.

Kunz, R. (2011). The political economy of global remittances: Gender, governmentality and neoliberalism. London: Routledge.

Lacoste, Y. (2006). Géopolitique: La longue histoire d'aujourd'hui. Paris: Larousse. 
Lahire, B. (2005). L'homme pluriel: Les ressorts de l'action. Paris: Armand Colin.

Laudicina, P., \& Peterson, E. (2016, January). From globalization to islandization: What will the next global economics order look like? Retrieved from: https://www.atkearney.com/web/global-business-policy-council/article?/a/from-globalization-to-islandizatio $\mathrm{n}$

Le Moigne, J. L. (1990). La modélisation des systèmes complexes. Paris: Dunod.

Lefebvre, H. (1968). Dialectical materialism (first published in 1940). London: Jonathan Cape Ltd.

Lenin, V. (1976). On the question of dialectics (1915). In Lenin's Collected Works (4 ${ }^{\text {th }}$ Edition, Volume 38, pp. 357-361), Moscow: Progress Publishers.

Levin, G. (2012). Embrace and exploit change as a program manager: Guidelines for success. Project Management Institute.

Lévy, J., Poncet, P. (2008). L'invention du monde: Une géographie de la mondialisation. Paris: Les Presses de Sciences Po.

Lipietz, A. (1979). Crise et inflation, pourquoi?. Paris: Maspero.

Lipietz, A. (1983). Le monde enchanté. De la valeur à l'envol inflationniste. Paris: La decouverte-Maspero.

Lordon, F. (2002). La politique du capital. Paris: Odile Jacob.

Lordon, F. (2009). La crise de trop - Reconstruction d'un monde failli. Paris: Fayard.

Lugan, J. C. (2010). La systémique sociale ( $5^{\text {th }}$ ed.). Paris: P.U.F.

Luttwak, E. N. (1990). From geopolitics to geo-economics. The National Interest, 17-24.

Mackinder, H. J. (1904). The geographical pivot of history. The Geographical Journal, 170(4), 298-321. https://doi.org/10.1111/j.0016-7398.2004.00132.x

Margulesku, E. (2015). Old and new economic globalization. Challenges of the Knowledge Society, 5(1), 739-742.

Marquis, C., \& Tilcsik, A. (2013). Imprinting: Toward a multilevel theory. Academy of Management Annals, 7(1), 195-245. https://doi.org/10.1080/19416520.2013.766076

Marshak, R. (2005). Contemporary challenges to the philosophy and practice of organization development. In D. L. Bradford \& W.W. Burke, Reinventing organization development: New approaches to change in organizations (pp. 19-42). New York: John Wiley \& Sons.

Mattli, W., \& Woods, N. (2009). The politics of global regulation. New Jersey: Princeton University Press. https://doi.org/10.1515/9781400830732

McKeon, R. (1954). Dialectic and political thought and action. Ethics, 65(1), 1-33. https://doi.org/10.1086/290973

Melé, D., Argandoña, A., \& Sanchez-Runde, C. (2011). Facing the crisis: Toward a new humanistic synthesis for business. Journal of Business Ethics, 99(1), 1-4. https://doi.org/10.1007/s10551-011-0743-y

Michalet, C. A. (1998). Le Capitalisme mondial. Paris: Presses Universitaires de France.

Milanovic, B. (2016). Global inequality: A new approach for the age of globalization. Cambridge, MA: Belknap Press. https://doi.org/10.4159/9780674969797

Miller, D. (1984). Organizations: A quantum view. New Jersey: Prentice Hall.

Mitroff, I. I., \& Silvers, A. (2009). Dirty rotten strategies: How we trick ourselves and others into solving the wrong problems precisely. CA, US: Stanford Business Books.

Narayanan, V. (2001). Managing technology and innovation for competitive advantage. London: Pearson.

National Intelligence Council (2008). Global trends 2025: A Transformed world, US NIC, Washington, DC. Retrieved from: http://www.dni.gov/files/documents/Newsroom/Reports\%20and\%20Pubs/2025_Global_Trends_Final_Rep ort

Nonaka, I., \& Kenney, M. (1991). Towards a new theory of innovation management: A case study comparing Canon, Inc. and Apple Computer, Inc. Journal of Engineering and Technology Management, 67-83. https://doi.org/10.1016/0923-4748(91)90005-C 
Orléan, A. (1999). Le pouvoir de la finance. Paris: Odile Jacob.

Orléan, A. (2009). De l'euphorie à la panique: Penser la crise financière. Paris: Rue d'Ulm.

Overbeek, H., \& van Apeldoorn, B. (2012). Neoliberalism in crisis. New York: Palgrave Macmillan. https://doi.org/10.1057/9781137002471

Palan, R. (2000). Global political economy: Contemporary theories. London: Routledge.

Passet, R. (1996). L'économique et le vivant ( $2^{\text {nd }}$ ed.). Paris: Economica.

Paunov, C. (2012). The global crisis and firms' investments in innovation. OECD, Directorate for Science, Technology and Industry, 41(1), 24-35. https://doi.org/10.1016/j.respol.2011.07.007

Peters, B., Pierre, J., \& Randma-Liiv, T. (2011). Global financial crisis, public administration and governance: Do new problems require new solutions? Public Organization Review, 11(1), 13-27. https://doi.org/10.1007/s11115-010-0148-x

Petit, P. (2005). Croissance et richesse des nations. Paris: La Découverte.

Philip, R. L. (2012). Financial globalisation and the crisis, BIS Working Paper No. 397.

Phillips, J. R. (1983). Enhancing the effectiveness of organizational change management. Human Resource Management, 22(1-2), 183-199. https://doi.org/10.1002/hrm.3930220125

Pieterse, J. N. (2011). Global rebalancing: Crisis and the East-South turn. Development and Change, 42, 22-48. https://doi.org/10.1111/j.1467-7660.2010.01686.x

Popper, K. (2014). Conjectures and refutations: The growth of scientific knowledge. New York: Routledge.

Popper, K. (2015). The open society and its enemies. New York: Routledge.

Porter, M. E. (1990). The competitive advantage of nations. New York: Free Press. https://doi.org/10.1007/978-1-349-11336-1

Postan, M. M. (1962). Function and dialectic in economic history. The Economic History Review, 14(3), 397-407. https://doi.org/10.1111/j.1468-0289.1962.tb00058.x

Prasad, E., Terrones, M., \& Kose, A. (2008). Does openness to international financial flows raise productivity growth?. IMF Working Papers 08/242.

Prigogine, I., \& Stengers, I. (1984). Order out of chaos. New York: Bantam.

Prigogine, I., \& Stengers, I. (1986). La nouvelle alliance: Métamorphose de la science. Paris: Gallimard.

Rainelli, M. (2011). L' organisation mondiale du commerce. Paris: La Découverte.

Reich, R. (1993). L'économie mondialisée. Paris: Dunod.

Reinert, E. (2008). How rich countries got rich . . . and why poor countries stay poor. New York: PublicAffairs.

Reinhart, C. M., \& Rogoff, K. S. (2009). The aftermath of financial crises. American Economic Review, 99(2), 466-472. https://doi.org/10.3386/w14656

Rifkin, J. (1997). La fin du travail. Paris: La Découverte.

Rifkin, J. (2002). L'Age de l'accès: La révolution de la nouvelle économie. New York: Pocket Books.

Rodrik, D. (2011). The globalization paradox: Democracy and the future of the world economy. New York: W. W. Norton \& Company. https://doi.org/10.1355/ae28-3k

Rogers, E. M. (1982). Diffusion of innovations ( $3^{\text {rd }}$ edition). New York: The Free Press.

Rosenfeld, R. B. (2008). All about people: Why leaders need to know the human side of innovation. Leadership in Action, 27(6), 13-17. https://doi.org/10.1002/lia.1228

Sánchez, M. (2010). Financial Innovation and the global crisis. International Journal of Business and Management, 5(11). https://doi.org/10.5539/ijbm.v5n11p26

Sartre, J. P. (1984). 001: Critique of dialectical reason: Theory of practical ensembles. Paris: Verso.

Schumpeter, J. A. (1911). Théorie de l'évolution économique. Paris: Dalloz.

Schumpeter, J. A. (1939). Business cycles (Vol. 1). New York: McGraw-Hill.

Schumpeter, J. A. (1942). Capitalism, socialism and democracy. New York: Harper \& Brother.

Servet, J. M. (2010). Le grand renversement: De la crise au renouveau solidaire. Paris: Desclée De Brouwer. 
Siles-Brügge, G. (2012). Europe and the management of globalization. Political Studies Review, 10(151). https://doi.org/10.1111/j.1478-9302.2011.00255_7.x

Sinclair, T. (2012). Global governance. Cambridge, UK: Polity Press.

Spranzi, M. (2011). The art of dialectic between dialogue and rhetoric: The Aristotelian tradition (Vol. 9). Amsterdam: John Benjamins Publishing. https://doi.org/10.1075/cvs.9

Steger, M. B. (2013). Political ideologies in the age of globalization. The Oxford Handbook of Political Ideologies, 214-231. https://doi.org/10.1093/oxfordhb/9780199585977.013.0025

Stiglitz, J. E. (2003a). Globalization and its discontents. New York: W. W. Norton \& Company.

Stiglitz, J. E. (2003b). La grande désillusion. Paris: Le Livre de Poche.

Sultanova, A. V., \& Chechina, O. S. (2016). Human capital as a key factor of economic growth in crisis. European Research Studies Journal, 0(2), 71-78.

Sveiby, K. E. (2012). Innovation and the global financial crisis: Systemic consequences of incompetence. International Journal of Entrepreneurship and Innovation Management, 16(1/2), 30-50. https://doi.org/10.1504/IJEIM.2012.050442

Tofler, A. (1970). Future shock. New York: Random House.

Tofler, A. (1980). The third wave. New York: Morrow.

Tofler, A. (1990). Powershift. New York: Bantam Books.

Tsoukas, H. (2017). Don't simplify, complexify: From disjunctive to conjunctive theorizing in organization and management studies. Journal of Management Studies, 54(2), 132-153. https://doi.org/10.1111/joms.12219

Tussman, M., \& Romanelli, E. (1994). Organization transformation as punctuated equilibrium: An empirical test. Academy of Management Journal, 37, 1141-1166. https://doi.org/10.2307/256669

Venette, S. J. (2003). Risk communication in a high reliability organization, APHIS PPQ's inclusion of risk in decision making.

Vlados, C. M, Deniozos, N., \& Chatzinikolaou, D. (2018). Towards a new approach of local development under crisis conditions: Empowering the local business ecosystems in Greece, by adopting a new local development policy. International Journal of Regional Development, 5(1). https://doi.org/10.5296/ijrd.v5i1.11955

Vlados, C. M. (1996). International restructuring dynamics of competitive advantages. Middle East FORUM, 1, 233-252.

Vlados, C. M. (2005). The insertion of Greek firms into globalization: The dynamics of the triangle of strategy, technology and management. Proceedings of Managing Global Trends and Challenges in a Turbulent Economy. University of the Aegean: Department of Business Administration.

Vlados, C. M. (2007). Development dynamics in South-Eastern Europe: The challenge of the new paradigm of cooperation. Middle East FORUM, 6.

Vlados, C. M. (2012). The search of competitiveness and the entrepreneurial evolution in a global environment: Towards a new approach of development dynamics based on the case of Greek productive system. Journal of Management Sciences and Regional Development, 8, 91-116.

Vlados, C. M., \& Katimertzopoulos, F. (2017). Local support mechanisms for entrepreneurship: The approach of local development and innovation institutions. International Journal of Business and Economic Sciences Applied Research, 10(1).

Vora, M. K. (2013). Business excellence through sustainable change management. The TQM Journal, 25(6), 625-640. https://doi.org/10.1108/TQM-07-2013-0080

Vujakovic, P. (2010). How to measure globalization? A new globalization index (NGI). Atlantic Economic Journal, 38(2), 237-237. https://doi.org/10.1007/s11293-010-9217-3

Wallerstein, I. (2012). Robinson's critical appraisal appraised. International Sociology, 27(4), 524-28. https://doi.org/10.1177/0268580912445532

Weick, K. E. (1999). Theory construction as disciplined reflexivity: Tradeoffs in the 90s. Academy of Management Review, 24(4), 797-806. 


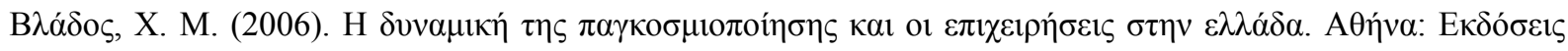
Крıєıки́.

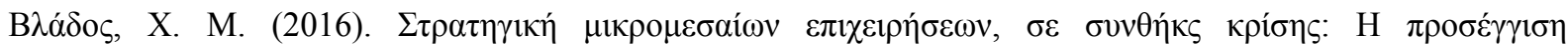

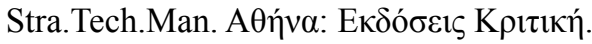

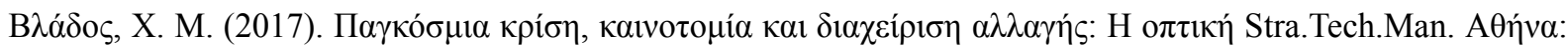

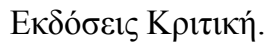

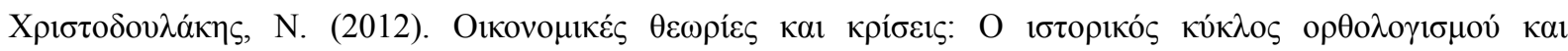

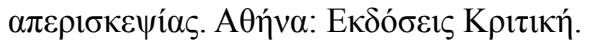

${ }^{[1]}$ Think of this diagram as the phenomenon of electricity. As it is known, the electric current is the oriented movement of electric loads or electricity carriers along a duct. The electrical current is generated by the potential difference between two points (from high potential points to low potential points). If there was no such difference, there would be no flow of electricity; this is also the case with globalization.

\section{Copyrights}

Copyright for this article is retained by the author(s), with first publication rights granted to the journal.

This is an open-access article distributed under the terms and conditions of the Creative Commons Attribution license (http://creativecommons.org/licenses/by/4.0/). 